\title{
THE SCOPE OF IMPLEMENTATION OF GEOMETRIC CONCEPTS IN SELECTED KINDERGARTENS IN POLAND
}

\author{
Anna Klim-Klimaszewska \\ University of Natural Sciences and Humanities in Siedlce, Poland \\ E-mail: anna.klim-klimaszewska@uph.edu.pl
}

\author{
Stanisława Nazaruk \\ Pope John Paul II State School of Higher Education in Biała Podlaska, Poland \\ E-mail: stnazaruk@poczta.onet.pl
}

\begin{abstract}
The core curriculum of preschool education stipulates that the child that is prepared to study Mathematics in school can distinguish between basic geometric figures (circles, squares, triangles, rectangles). Nevertheless, a review of the records of student training in kindergarten revealed that there were no geometry-related subjects in any of them. Therefore, it was decided to further explore whether it was the teachers who did not implement geometrical concepts or just the students, who had no opportunity to observe or conduct classes in the field. In addition, if the latter was the case, the analysis was to include the extent to which teachers implement geometric concepts.A total of 150 teachers (females only), 78 teachers from 19 kindergartens located in Siedlce and 72 teachers from 18 kindergartens located in Biala Podlaska, participated in the research. The research methods of a diagnostic survey and document review were employed. Structured interviews were conducted with the teachers in order to identify the factors having an influence on the implementation of geometric concepts in kindergartens. The content analysis of geometry topics recorded in class registers was performed for the period of 8 months. The analysis of research results revealed that, in most cases, there was no systematic mathematical education with geometric content provided by most of the teachers participating in the research.

They do not use children's potential, i.e. geometric intuition, in an effective way. However, if properly shaped in kindergarten, this intuition may be a baseline for a more systematic study of Mathematics, including geometry, in school. On the basis of this research, conclusions may be drawn about the scope of geometrical education in kindergartens.
\end{abstract}

Keywords: content analysis, geometrical education, geometrical concepts, preschool education.

\section{Introduction}

It is generally acknowledged that geometry should be first taught between the age of 6 and 7, when actions which limit themselves to the child's mind begin to form. However, both research and pedagogical practice indicate that as early as at the pre-operational stage, i.e. in children aged 2-6, "geometric intuition" begins to appear. It develops in little children through everyday hands-on experience (Gruszczyk-Kolczyńska, Zielińska, 1997, pp. 125128; Gruszczyk-Kolczyńska, Zielińska, 2004, pp. 267-270; Hejny, 1993, 1995; Krygowska, Nowecki, 1992; Piaget, Inhelder, 1967, p. 137; Wygotski, 1971, pp. 212-487).

Eagerness of children to explore everything that surrounds them using all senses seems unexhausted. As it also refers to different objects, children very quickly develop the ability to distinguish between individual shapes. The child observes, touches, moves, turns round, changes the shape etc. Then, the child's mind goes on to isolate the most important factors (Gruszczyk-Kolczyńska, Zielińska, 1997, p. 127). Such multi-sensory method of discovering 
Anna KLIM-KLIMASZEWSKA, Stanisława NAZARUK. The scope of implementation of geometric concepts in selected kindergartens in Poland

PROBLEMS

OF EDUCATION

IN THE $21^{\text {st }}$ CENTURY Vol. 75 , No. 4, 2017

346

the world around provides the child with a number of incentives, which stimulate the association neurons, and with positive emotions, such as joy, interest, astonishment, which stimulate the process of learning (Ntalakoura, Ravanis, 2016).

An average-level two-year old can fit various shape plates into holes in a small plank (circles, squares, triangles). In his third year, the precision in observing shapes increases enough for the child to be able to draw a circle or a loop, or differentiate between an ellipse and a cylinder shape (Hurlok, 1996, p. 496).

A typical four-year old can draw not only a circle but also a square. At the age of five, the ability to distinguish between individual figures is even more enhanced. Six-year olds, in turn, accept geometrical shapes, such as circles, squares, triangles, etc. as characteristic features of existing and recognizable things (Franus, 1975, pp. 60-61). Thus, a preschool child may successfully learn geometry.

Having in mind the overview of the issue of children's perception of geometrical concepts within the context of child development, there is one more factor to the process, which should be indicated, and it is the didactic method. Needless to say, the teacher has the key role to play here, for he implements geometry-related contents in line with the core curriculum, setting objectives and methods of teaching of his own choosing. Many specialists in the field, both in Poland (Gruszczyk-Kolczyńska, Zielińska, 1997; Klim-Klimaszewska, 2010) and abroad (Kampeza, Vellopoulou, 2016; Gallegos-Cazares, Flores-Camacho, Calderon-Canales, 2009), have drawn attention to proper application of didactic methods in the process of preschool education. The development of geometrical intuition occurs, in particular, thanks to the observation of our surroundings, the search for various shapes, the work with diverse aid types, such as: a geometric cabinet or a chest of drawers, block towers, wooden geometric solids, wooden blocks of various shapes, colours, and textures, scraps of fabrics, geometric puzzles, geometric forms on pieces of paper of various thickness and texture, different types of spheres, balls, dices, beads for arranging and stringing, figure sets for hammer-type toys, etc.

The common feature of all didactic methods applied in preschools, including those referring to mathematical education, is the holistic approach (Fleer, 2002; Sikder, Fleer, 2015). More and more professionals highlight the need to incorporate the holistic approach into the methods of teaching in preschools. Within the context of individual predispositions to find the way to support the child's holistic learning, recommendations can be found in the report over research conducted by Katri-Liis Vainio and Rea Raus (2014, pp. 167-184), who availed of the Myers-Briggs type indicator (MBTI). They underline that the quality of geometrical education in preschools is affected by a number of factors, including but not limited to teachers' professional competencies. In relation to geometry, which is a constituent of Mathematics, teachers' use of innovative technologies and advances in neurobiology and the need to conduct research on the quality of teaching have come to the forefront (Lamanauskas 2014, pp. 5-7). As V. Lamanauskas (2014, p. 5) rightly notes, in the last decade, the youth's interest in science and technology decreased in numerous countries. Therefore, an effectively conducted preschool geometrical education is crucial to the process of further school education.

Having in mind the preschool child's needs to discover geometry and the role of geometry in school education, and considering the lack of geometry-related research, it seems therefore that such analyses ought to be conducted.

The main research problem was stated in the form of the following question: 'What, if any, geometric concepts were introduced by the teachers in selected kindergartens?'. The more specific research problems were formulated as follows:

1. What geometric content was introduced in selected kindergartens over a period of eight months, from September 2016 to April 2017?

2. How often were geometric concepts introduced to kindergarten children, how many times a week and how many times a month?

3. What factors have an influence on the implementation of geometric concepts in kindergartens? 
4. What, if any, factors could facilitate the implementation of geometric education in kindergartens?

\section{Methodology of the Research}

\section{General Background}

The conducted research dovetails with the educational research on geometry knowledge and skills of pre-school children. This issue needs to be further examined since no research on that topic has been performed in Poland so far. The research was conducted in 37 kindergartens located in Siedlce and Biala Podlaska. Such a large number of kindergartens taking part in the research were motivated by the scope of the studied phenomenon. Furthermore, it should be mentioned that there are two institutions of higher education in the cities, the students of which cooperate with kindergartens. The pedagogy students undergo practical training there and organize a variety of educational activities for kindergarten children. The above mentioned factors facilitated the process of organisation and performance of the research.

\section{Procedure}

There were two stages of the research. The first one involved the review of documents, which included class registers from kindergartens. The analysis covered the entries concerning geometric concepts which were recorded in the documents by the teachers having classes with kindergarten kids over the period of 8 months, namely from September 2016 to the end of April 2017. The separate analysis of kindergarten class registers was conducted for the groups of children aged 3, 4, 5 and 6 years. The second stage of this research involved conducting individual interviews with 150 teachers working in kindergartens located in Siedlce and Biala Podlaska. Each teacher was asked the questions from the list included in the interview questionnaire. The questions were targeted at identifying factors influencing the implementation of geometric concepts in kindergartens. The structured interviews were conducted in April, 2017.

\section{Participants}

The research was performed on 150 teachers working in kindergartens located in two cities in Poland. This number of teachers is the result of their eagerness and wish to participate in this survey. 78 teachers working in 19 public kindergartens located in Siedlce and 72 teachers working in 18 public kindergartens located in Biala Podlaska took part in the research. The age of the respondents was not taken into consideration as it was presumed that this variable was of no importance for this research. The teachers participating in the research lived in the cities in which the kindergartens were located. For the document review, in turn, class registers were made available by the teachers, with the consent of competent authorities. The total number of the reviewed registers was 150 as separate class registers of four age groups (three, four, five and six- year-olds) were analysed in each kindergarten.

\section{Data Analysis}

Data analysis was based, in the first place, on the analysis of geometry topics which were recorded by the teachers in their class registers. Data analysis results were entered into specially prepared summary data sheets, which included topics in geometry, their frequency and a child's age. Then, the results of individual interviews with the teachers were summarized in tables and the percentages were calculated. 
Anna KLIM-KLIMASZEWSKA, Stanisława NAZARUK. The scope of implementation of geometric concepts in selected kindergartens in Poland

PROBLEMS

OF EDUCATION

IN THE $21^{\text {st }}$ CENTURY Vol. 75 , No. 4, 2017

348

\section{Results of Research}

Table 1 presents geometry topics, which were introduced to groups of children aged 3-4 and children aged 5-6 from September 2016 to the end of April 2017. The topics were recorded in class registers of 23 teachers.

\section{Table 1. Geometry topics covered by the teachers}

\begin{tabular}{|c|c|c|c|}
\hline \multirow[b]{2}{*}{ No. } & \multirow[b]{2}{*}{ Geometry topics } & \multicolumn{2}{|c|}{ The child's age } \\
\hline & & $\begin{array}{l}3-4 \\
\text { years }\end{array}$ & $\begin{array}{l}5-6 \\
\text { years }\end{array}$ \\
\hline 1. & Colourful puppet clown - a flat, colourful paper cut out composed of geometric figures & $\mathrm{x}$ & \\
\hline 2. & Circle-shaped objects - a didactic game & & $\mathrm{x}$ \\
\hline 3. & Distinguishing the circle shape - a game using colourful small circles & & $\mathrm{x}$ \\
\hline 4. & Circles and little circles - a Mathematical game & & $\mathrm{x}$ \\
\hline 5. & $\begin{array}{l}\text { Button puzzles - looking for circles in the room Reconstructing the shapes of geometric } \\
\text { figures }\end{array}$ & & $\mathrm{x}$ \\
\hline 6. & Reconstructing the shapes of geometric figures & & $\mathrm{x}$ \\
\hline 7. & Making balls out of newspapers & & $\mathrm{x}$ \\
\hline 8. & Square - games involving geometric figures & & $\mathrm{x}$ \\
\hline 9. & Which ball is bigger? - a Mathematical game & & $\mathrm{x}$ \\
\hline 10. & Let's make snowballs - an outdoor activity & $\mathrm{x}$ & \\
\hline 11. & Cutting out along a straight, broken or a curved line & & $\mathrm{x}$ \\
\hline 12. & Consolidating shapes and names of geometric figures & & $\mathrm{x}$ \\
\hline 13. & Artistic works composed of geometric figures & & $\mathrm{x}$ \\
\hline 14. & Introducing children to the ruler as a geometrical tool & & $\mathrm{x}$ \\
\hline 15. & Introducing children to the straight and broken line & & $\mathrm{x}$ \\
\hline 16. & Looking around for the recognised shapes & & $\mathrm{x}$ \\
\hline 17. & Colourful signs - distinguishing between shapes in road signs & & $\mathrm{x}$ \\
\hline 18. & My dream car - cutting out shapes, adding elements in the shape of geometric figures & & $\mathrm{x}$ \\
\hline 19. & Ball - introducing children to the sphere & $\mathrm{x}$ & $\mathrm{x}$ \\
\hline 20. & Building using large spatial blocks - using the term "cube" & & $\mathrm{x}$ \\
\hline 21. & Sphere or circle - finding differences & & $\mathrm{x}$ \\
\hline 22. & Making patterns of geometric figures & & $\mathrm{x}$ \\
\hline 23. & Rhythms - making rhythms of squares, circles and triangles & & $\mathrm{x}$ \\
\hline 24. & Revision of characteristic features of a square, triangle and a rectangle & & $\mathrm{x}$ \\
\hline 25. & Is it ... - distinguishing a square from a rectangle & & $\mathrm{x}$ \\
\hline 26. & Making paper balls & $\mathrm{x}$ & - \\
\hline 27. & Finding shapes of plane and solid geometric figures in everyday objects & & $\mathrm{x}$ \\
\hline 28. & A triangle fairy tale - a Mathematical story & $\mathrm{x}$ & \\
\hline 29. & Road signs and geometric figures - a Mathematical game & & $\mathrm{x}$ \\
\hline 30. & Making any spatial compositions of blocks in the shape of geometric figures & $\mathrm{x}$ & $\mathrm{x}$ \\
\hline 31. & Let's make a snowman and a house for the winter - a spatial game & $\mathrm{x}$ & $\mathrm{x}$ \\
\hline 32. & Consolidation of names and appearance of geometric figures & & $\mathrm{x}$ \\
\hline 33. & Circle and sphere - plane and solid figures, what makes them different? & & $\mathrm{x}$ \\
\hline 34. & Colourful circles - playing with circles & $\mathrm{x}$ & $\mathrm{x}$ \\
\hline 35. & Creating a snowman silhouette using circles & $\mathrm{x}$ & $\mathrm{x}$ \\
\hline 36. & Paper Christmas tree - origami technique using circles & & $\mathrm{x}$ \\
\hline 37. & Chasing the square - games and exercises & & $\mathrm{x}$ \\
\hline 38. & Triangles - a game involving physical movement & & $\mathrm{x}$ \\
\hline 39. & Getting to know the rectangle - introducing the name and features of the rectangle & & $\mathrm{x}$ \\
\hline 40. & Obedient figures - a game consolidating recognised geometric figures & & $\mathrm{x}$ \\
\hline 41. & Sorting figures - a game & & $\mathrm{x}$ \\
\hline 42. & Making silhouettes of fairy tale characters using geometric figures & & $\mathrm{x}$ \\
\hline 43. & Counting figures - adding practice & & $\mathrm{x}$ \\
\hline 44. & Games involving geometric figures & & $\mathrm{x}$ \\
\hline 45. & Making patterns using geometric figures & & $\mathrm{x}$ \\
\hline
\end{tabular}


The data analysis provided in Table 1 shows that 23 teachers implemented 45 geometry

PROBLEMS
OF EDUCATION
IN THE $21^{\text {st }}$ CENTURY
Vol. 75, No. 4, 2017

349 topics in the period of 8 months. Taking into consideration the analysis period, namely 8 months, it should be stated that on average 6 topics were implemented in a month. With reference to a week, this average is very low as it makes only 1.4. Regarding the implementation of geometric content in different age groups, it can be noticed that only 9 topics were covered in the group of 3-4 year-old children. It can thus be concluded that, on average, the geometry topics were introduced once a month. However, in a kindergarten group of children aged 5-6 years, more entries connected with geometry were observed in the registers, namely 5 topics a month, which makes one topic a week.

In 65 kindergarten class registers, no topics pertaining to geometry were recorded, only single concepts were introduced in the context of other subjects. Since the compilation of topics covered during the period of 8 months was too extensive and, at the same time, the number of geometric concepts was similar, Table 2 presents the topics implemented in one month (September 2016).

Table 2. Types of geometric concepts.

\begin{tabular}{|c|c|c|c|c|}
\hline \multirow[b]{2}{*}{ No. } & \multirow[b]{2}{*}{ Lesson topic } & \multirow[b]{2}{*}{ Geometric concepts } & \multicolumn{2}{|c|}{ The child's age } \\
\hline & & & $3-4$ years & $\begin{array}{l}5-6 \\
\text { years }\end{array}$ \\
\hline 1. & Adding a few and subtracting a few & $\begin{array}{l}\text { A square, a rectangle, a circle, a } \\
\text { pentagon }\end{array}$ & & $x$ \\
\hline 2. & Houses in Autumn & A square, a triangle, a rectangle & & $\mathrm{x}$ \\
\hline 3. & Daisies live in the grass & A circle & $\mathrm{x}$ & \\
\hline 4. & $\begin{array}{l}\text { Let's make calendars - 'The four } \\
\text { seasons' }\end{array}$ & A circle & $x$ & $x$ \\
\hline 5. & Bees and ladybugs on a meadow & A circle & $\mathrm{x}$ & \\
\hline 6. & Mathematical games with a Teddy Bear & Plane figures: a triangle, a square & & $\mathrm{x}$ \\
\hline 7. & Construction games & Solid figures: a cube, a sphere & & $\mathrm{x}$ \\
\hline
\end{tabular}

As shown in Table 2, 65 kindergarten teachers introduced a very limited number of geometric concepts during pre-school activities, which may hinder the process of learning and understanding geometry. The reasons behind this lack of geometric curricular content given by the teachers were as follows: 'getting to know one concept in geometry while learning different curricular content fully satisfies the requirements of the core curriculum of preschool education for kindergartens'. Thus, in reference to the above mentioned statement, it should be stated that this group of teachers does not see and does not put into practice typical geometric content.

In the case of 62 teachers, there were no records of geometric curricular content in the class registers. When interviewed, the teachers admitted that in accordance with the core curriculum for kindergartens they should teach content concerning basic plane and solid figures; however, methodological books did not include ready-made lesson plans for such pre-school activities. As a consequence, the geometric content was disregarded by them.

The data presented in Table 1 and 2 give cause for concern as teachers do not encourage and support the intellectual development of children as far as geometry is concerned, which may result in learning difficulties. Hence, it seemed natural for the research process to conduct additional interviews with teachers working in kindergartens, so that the factors which had an impact on the implementation of geometry-related contents could be discovered. All teachers were qualified to work as preschool teachers. Their competencies with regards to the teaching of Maths were based mainly on their college knowledge and skills. However, it appears that the number of hours devoted to mathematical education in preschool teachers' training curricula is low and amounts to 20-30 hours per entire university programme. After graduation, only $10 \%$ of the study teachers completed a supplementary teacher training course in Mathematics. 
Anna KLIM-KLIMASZEWSKA, Stanisława NAZARUK. The scope of implementation of geometric concepts in selected kindergartens in Poland

PROBLEMS

OF EDUCATION

IN THE $21^{\text {st }}$ CENTURY Vol. 75 , No. 4, 2017

Nevertheless, those attending such courses claimed that, with time, they tended to forget what they had learnt and hence, they could not be so certain about their geometrical knowledge. That was also the reason why they did not implement said topics in kindergartens. The remaining $90 \%$ of the teachers never enrolled in any courses or trainings associated with the field.

It is well known that over the course of time some information is forgotten, which makes teachers who recognise the limitations of their geometric knowledge avoid tackling such topics in the kindergarten classroom. When asked about the reasons for the lack of geometry topics in kindergarten, the teachers presented a number of answers which are shown it Table 3.

Table 3. The reasons for lack of geometry in kindergarten.

\begin{tabular}{lll}
\hline No. & The reasons for lack of geometry & $\%$ \\
\hline 1. & Lack of geometry lesson plans & 40 \\
\hline 2. & A shortage of training in geometry teaching methodology for kindergarten teachers & 35 \\
\hline 3. & Lack of teaching aids for geometry & 12 \\
\hline 4. & Lack of interest on the part of kindergarten children & 8 \\
\hline 5. & Other & 5 \\
\hline & Total & 100 \\
\hline
\end{tabular}

Personal factors, e.g. the lack of willingness to participate in training, to prepare teaching aids on their own, to use scientific publications or the lack of initiative in preparing lesson plans for geometry were not mentioned by any of the teachers.

The teachers were also asked the question on the lesson individualisation in kindergarten. It was demonstrated that $85 \%$ of the teachers conducted classes focusing on early support for development of children. Around $80 \%$ of the teachers completed competence courses qualifying them to conduct such classes. Yet, none of the teachers conducted classes supporting children's mathematical skills. This absence of professional support with regards to children and their interest in Maths at the beginning of the educational path, i.e. kindergarten, may constitute an obstacle to learning Mathematics in school, or the reason behind kids aversion to participate in mathematical competitions, contests etc. The above examples prove that the lack of teacher competencies has a negative impact on the implementation of geometrical curricular contents, on the creation of the organisation of the process of learning, and on the development of children's talents.

\section{Discussion}

In Poland, with regards to the didactic and educational work, all preschools implement the same Core Curriculum for Preschool Education, wherein the Polish Ministry for National Education included the mathematical skills (also those in the field of geometry) that a child aged six should be equipped with. The above specified document does not set forth any detailed geometrical concepts or recommendations regarding the use of methods by preschool teachers. This issue was left open for teachers, who compose detailed descriptions of mathematical education contents to be realised in a given group of children, in a given week, month and year. We will find no summaries of mathematical achievements of preschool children in Polish literature. There are only reports concerning mathematical skills of students graduating from primary and lower secondary schools. However, the 2015 report issued by the Educational Research Institute on the diagnosis of professional competence of early school education demonstrated that more than $50 \%$ of teachers showed low mathematical competences: " $55 \%$ of early school education teachers said it was possible to divide by zero". Furthermore, it turned out that a large portion of teachers did not cope with mathematical tasks which appeared in competitions, which means that they either use fixed sets of exercises or they do not work with mathematically gifted pupils. This example illustrates the need to support teachers in the area of 
working with gifted students (Czajkowska, Grochowalska, Orzechowska, 2015). On the other hand, the cited data confirm that research regarding the quality of mathematical education in kindergartens is requisite. In the USA, there are studies which diagnose pupils' mathematical achievements as early as in kindergarten. In 2002, Denton and West published a comprehensive report on children's mathematics achievement in kindergarten and first grade (Denton, West, 2002). What is more, in the specialist reports developed by the Boston College, referring to children's technical (and also mathematical) skills, there is an age differentiation as well (4, 5 and 6-year olds) (Martin, Mullis, Kennedy, 2001).

Within the broad context of a variety of factors influencing mathematical skills of preschool children, attention should be paid to their utmost importance in child development. Math or geometry lesson activities stimulate child's imagination; develop memory, operational reasoning, logical thinking, perceptiveness and attention. Furthermore, such activities improve cognitive mechanisms and graphomotor skills. They also enhance knowledge, help to acquire new experiences, stimulate cognitive curiosity and activate spatial imagination. Moreover, math or geometry lessons create situations in which children can experience positive effects of their own actions. They also help children to create a positive self-image and overcome fears of problematic situations. Geometric intuition, if properly developed in kindergarten, is the starting point for pursuing systematic mathematics education, including geometry, at school. Thus, kindergarten is the place where children should be attracted to the world of mathematics, encouraged to make effort to improve their knowledge. Furthermore, kindergartens should emotionally and intellectually prepare children for learning mathematics at school.

\section{Conclusions}

The research has shown that the majority of the interviewed kindergarten teachers do not provide systematic geometric education. The role of the teachers, who do implement some geometric concepts, is limited to introducing only the geometric content enumerated in the core curriculum.

The implementation of the geometric content in different age groups in the studied kindergartens is not sufficient. Furthermore, lack of such education was revealed in some kindergarten groups, which may have an adverse influence on the process of education in primary schools not only when it comes to mathematics, but also in the case of other subjects and other developmental spheres (emotional and cognitive).

The lack of additional training in mathematics and geometry has also been found among the surveyed group of kindergarten teachers, which has a negative influence on their teaching competence. It seems therefore necessary for some of the teachers to continue their professional development in the field of mathematical education, both in its content and methodology. The implementation of the geometric content is also hindered to some extent by the lack of available publications on geometric education in kindergartens. The existing publications on kindergarten mathematics include very little information on the geometric content of mathematics education or they mainly include issues closely related to the implementation of the core curriculum for kindergartens. However, there are no methodological books solely devoted to the implementation of geometric education in kindergartens or extending the content, recommended in the core curriculum. This is particularly damaging to the educational process of kindergarten children.

It seems necessary to deliver more individualized activities in order to stimulate the development of children's aptitude for mathematics and geometry. The lack of professional support for their interest in mathematics at the very beginning of their education may present an obstacle to learning math at school or even discourage children from participating in mathematical competitions.

The analysis of the research data has shown that there is a need for the effective geometric education in kindergartens because of its huge impact on child development. Therefore, it seems advisable to conduct further research in order to develop geometry education programmes addressed at/targeted at kindergarten children, which is undoubtedly a great inspiration. 
Anna KLIM-KLIMASZEWSKA, Stanisława NAZARUK. The scope of implementation of geometric concepts in selected kindergartens in Poland

PROBLEMS

OF EDUCATION

IN THE $21^{\text {st }}$ CENTURY Vol. 75 , No. 4, 2017

352

\section{References}

Czajkowska, M., Grochowalska, M., Orzechowska, M. (2015). Potrzeby nauczycieli edukacji wczesnoszkolnej $i$ nauczycieli matematyki $w$ zakresie rozwoju zawodowego [The needs of early school education teachers and teachers of Mathematics with regards to professional development]. Warszawa: IBE.

Denton, K., West, J. (2002). Children's reading and mathematics achievement in kindergarten and first grade. Washington DC, USA: National Center for Education Statistics.

Fleer, M. (2002). Sociocultural theory: Rebuilding the theoretical foundations of early childhood education. Policy and Practice in Education, 54 (1), 105-120.

Franus, E. (1975). Sprawdziany rozwoju dziecka. Od urodzenia do szóstego roku życia [Tests of child's development. From birth to the age of six]. Warszawa: Nasza Księgarnia.

Gallegos-Cazares, L., Flores-Camacho, F., \& Calderon-Canales, E. (2009). Preschool science learning: The construction of representations and explanations about colour, shadows, light and images. Review of Science, Mathematics and ICT Education, 3 (1), 49-73.

Geske, A., Ozola, A., (2008). Factors influencing reading literacy at the primary school leve. Problems of Education in the 21st Century, 6 (6), 71-77.

Gruszczyk-Kolczyńska, E., Zielińska, E. (1997). Dziecięca matematyka. Ksiażka dla rodziców $i$ nauczycieli [Child Mathematics. A book for parents and teachers]. Warszawa: WSiP.

Gruszczyk-Kolczyńska, E., Zielińska, E. (2004). Wspomaganie rozwoju umysłowego czterolatków $i$ pięciolatków [Supporting mental development of four- and five-year olds]. Warszawa: WSiP.

Hejny, M. (1993). The understanding of geometrical concepts. In: Proceedings of the 3-rd Bratislava International Symposium on Mathematical Education BISME - 3. Bratislava: University J.A. Komenskeho.

Hejny, M. (1995). Development of geometrical concepts. In: International Symposium on Elementary Maths Teaching SEMT '95. Prague: Charles University Faculty of Education.

Hurlok, E. B. (1996). Rozwój dziecka [Child development]. Warszawa: PWN.

Kampeza, M., Vellopoulou, A., Fragkiadaki, G., Ravanis, K. (2016). The expansion thermometer in preschoolers' thinking. Journal of Baltic Science Education, 15 (2), 185-193.

Klim-Klimaszewska, A. (2010). Pedagogika przedszkolna. Nowa podstawa programowa [Preschool pedagogy. New core curriculum]. Warszawa: Erica.

Krygowska, Z., Nowecki, B. (1992). Kształtowanie pojęć matematycznych u dziecka [Shaping mathematical concepts in children] in: Z. Semadeni (Ed.), Nauczanie poczatkowe matematyki. Podręcznik dla nauczyciela [....]. vol. 2. Warszawa: WSiP.

Lamanauskas, V. (2014). Science and math teachers' collaboration: How to develop it seeking pupil's success at school. Problems of Education in the 21st Century, 62 (62), 5-7.

Martin, M. O., Mullis, I. V. S., \& Kennedy, A. M. (Eds.) (2003). PIRLS 2001 technical report. Chestnut Hill MA, USA: Boston College.

Ntalakoura, V., Ravanis, K. (2016). Changing preschool children's representations of light: A scratch based teaching approach. Journal of Baltic Science Education, 13 (2), 191-198.

Piaget, J., Inhelder, B. (1967). Obrazy umysłowe [Mental images]. In: P. Oléron, J. Piaget, B. Inhelder, P. Gréco (ed.), Inteligencja [Intelligence]. Warszawa: PWN.

Sikder, S., \& Fleer, M. (2015). Incremental science learning in toddler's play. International Journal of Science Education - Part B, DOI:10.1080/21548455.2015.1020457.

Vainio K. L., Raus, R. (2014). Using selected personality variables in a learning process for holistic education: A case of a voice training course participants. Problems of Education in the 21st Century, 60 (60), 167-184.

Wygotski, L. S. (1971). Wybrane prace psychologiczne [Selected psychological works]. Warszawa: PWN.

Annex I to the Minister for National Education Regulation of 14 February 2017 on the Core curriculum of pre-school education for preschools, preschool departments in primary schools, and other forms of pre-school education, J. of Laws of 24 February 2017, Item 356. 
Anna KLIM-KLIMASZEWSKA, Stanisława NAZARUK. The scope of implementation of geometric concepts in selected kindergartens in Poland

Received: June 11, 2017

Accepted: August 16, 2017

\begin{tabular}{|l} 
PROBLEMS \\
OF EDUCATION \\
IN THE 21 $1^{\text {st }}$ CENTURY \\
Vol. 75, No. 4, 2017 \\
\hline 353
\end{tabular}

\begin{tabular}{|ll|}
\begin{tabular}{|l|l|} 
Anna \\
Klim-Klimaszewska
\end{tabular} & $\begin{array}{l}\text { Professor, Head of the Department of Teacher Education, } \\
\text { University of Natural Sciences and Humanities in Siedlce, Faculty of Hu- } \\
\text { manities, Institute of Education, ul. Żytnia 39, 08-110 Siedlce, Poland. } \\
\text { E-mail: anna.klim-klimaszewska@uph.edu.pl, klimanius@interia.pl } \\
\text { Website: http://www.kd.ip.uph.edu.pl }\end{array}$ \\
\hline $\begin{array}{l}\text { Stanisława Katarzyna } \\
\text { Nazaruk }\end{array}$ & $\begin{array}{l}\text { PhD, Pope John Paul II State School of Higher Education in Biala Podlaska, } \\
\text { Faculty of Humanities and Social Sciences, Department of Education, ul. } \\
\text { Sidorska 95/97, 21-500 Biała Podlaska, Poland. } \\
\text { E-mail: stnazaruk@poczta.onet.pl, stnazaruk@poczta.onet.pl }\end{array}$
\end{tabular}

